\title{
Ovarian Function in Girls with McCune-Albright Syndrome ${ }^{1}$
}

\author{
CAROL M. FOSTER, PENELOPE FEUILLAN, VASANTHA PADMANABHAN, ORA H. PESCOVITZ, \\ INESE Z. BEITINS, FLORENCE COMITE, THOMAS H. SHAWKER, D. LYNN LORIAUX, AND \\ GORDON B. CUTLER, JR. \\ Developmental Endocrinology Branch, National Institute of Child Health and Human Development, \\ Bethesda, Maryland 20892 [C.M.F., P.F., O.H.P., F.C., D.L.L., G.B.C.]; Department of Pediatrics, University of \\ Michigan Medical Center, Ann Arbor, Michigan 48109 [C.M.F., V.P., I.Z.B.]; and Diagnostic Radiology, \\ Clinical Center, National Institutes of Health, Bethesda, Maryland 20892 [T.H.S.]
}

\begin{abstract}
We measured plasma estradiol levels and ovarian volumes in eight girls with precocious puberty due to McCune-Albright syndrome. Six girls had gonadotropinindependent ovarian estrogen secretion and two girls had pubertal gonadotropin levels. Mean ovarian volume in all patients was significantly greater than in normal prepubertal girls. Mean ovarian volumes of the girls with McCuneAlbright syndrome overlapped the range found in girls with idiopathic central precocious puberty or central precocious puberty associated with central nervous system lesions. However, the degree of asymmetry between the right and left ovaries was significantly greater in girls with McCuneAlbright syndrome. Asymmetry was due, for the most part, to the presence of large solitary cysts in the larger of the two ovaries. In the six girls with McCune-Albright syndrome and gonadotropin-independent precocious puberty, both mean ovarian volume and the degree of asymmetry between the right and left ovaries were significantly correlated with plasma estradiol. Serum follicle-stimulating hormone bioactivity was increased in two patients but did not vary with ovarian cyst size. Thyroid-stimulating hormone levels were normal but serum prolactin was slightly elevated in one of the six girls with gonadotropin-independent precocious puberty. Fluctuation in the size of unilateral ovarian cysts appears to result in changes in the plasma estradiol level, leading to advancement and spontaneous regression of secondary sexual characteristics and menses in girls with McCune-Albright syndrome. The cause of the cyst formation is unknown but may be related to periodic elevation of as yet undefined serum factors such as follicle-stimulating hormone bioactive substances. (Pediatr Res 20: 859-863, 1986)
\end{abstract}

\section{Abbreviations}

FSH, follicle-stimulating hormone

TSH, thyroid-stimulating hormone

LH, luteinizing hormone

LHRH, luteinizing hormone-releasing hormone

CNS, central nervous system

hCG, human chorionic gonadotropin

Received February 24, 1986; accepted April 25, 1986.

Address correspondence to Carol M. Foster, M.D., Department of Pediatrics, University of Michigan, C. S. Mott Hospital F2125, Ann Arbor, MI 48109.

${ }^{1}$ Presented in part before the Society for Pediatric Research, San Francisco, CA, May 1984.
Girls with McCune-Albright syndrome have fibrous dysplasia of bone associated with café-au-lait skin pigmentation and/or precocious puberty $(1,2)$. Advancement and regression of secondary sexual characteristics and episodes of menses in these girls often follow a cyclical course $(3,4)$ and in most girls, are independent of pubertal secretion of gonadotropins (3-6). In fact, gonadotropin levels are frequently suppressed below prepubertal levels (5).

Regression of secondary sexual characteristics in girls with McCune-Albright syndrome has been observed when ovarian cysts or wedge sections of ovaries have been removed $(7,8)$. Comite et al. (4) observed that in one girl with McCune-Albright syndrome, fluctuation of the size of a left ovarian cyst was associated with increases and decreases of plasma estradiol levels. In order to explore this association further, we compared ovarian volume and estradiol levels in eight girls who had precocious puberty associated with McCune-Albright syndrome. We have attempted to determine the etiology of cyst formation by examining serum FSH bioactivity and TSH and prolactin concentrations.

\section{METHODS}

Subjects. The initial clinical and laboratory findings of the eight girls with McCune-Albright syndrome are indicated in Table 1. All girls had fibrous dysplasia of bone and precocious puberty. Patients 1, 2, 4, and 6 had café-au-lait skin pigment: tion. Patients 1 and 6 had extensive lower limb deformities with subsequent height loss. Patients 1 through 6 had prepubertal or suppressed gonadotropin levels whereas patients 7 and 8 had pubertal nocturnal LH pulsations and a pubertal gonadotropin response to injection of LHRH. Neoplasms were not detected by computed tomography of the head or by ultrasonography of the pelvis and adrenal glands. Plasma 17-hydroxyprogesterone and 11-deoxycortisol, measured to exclude congenital adrenal hyperplasia, were normal. Serum $T_{4}$ levels were also normal.

Girls with central precocious puberty, either idiopathic $(n=$ 33 ) or associated with a CNS lesion $(n=8)$, ranged from 1 to 18 yr of age. All had stage II or greater pubertal development [according to the method of Tanner (9)], advanced bone age for chronological age, and accelerated height velocity. All had a pubertal response of gonadotropins in response to LHRH and/ or nocturnal pulsations of LH. Girls were included for study only after exclusion of ovarian or adrenal neoplasms by ultrasonography, and all had normal serum 17-hydroxyprogesterone and 11-deoxycortisol.

Protocol. Patients were admitted to the Clinical Center of the National Institutes of Health. The protocol was approved by the Clinical Research Committee of the National Institute of Child 
Table 1. Clinical and hormonal characteristics*

\begin{tabular}{|c|c|c|c|c|c|c|c|c|c|c|}
\hline \multirow[b]{2}{*}{ Patient } & \multirow[b]{2}{*}{$\begin{array}{l}\text { Age } \\
(\mathrm{yr})\end{array}$} & \multirow[b]{2}{*}{$\begin{array}{c}\mathrm{Ht} \\
(\mathrm{cm})\end{array}$} & \multirow[b]{2}{*}{$\%$} & \multicolumn{4}{|c|}{ Pubertal stage $\dagger$} & \multicolumn{3}{|c|}{ Peak response to LHRH } \\
\hline & & & & $\begin{array}{c}\text { Bone } \\
\text { age } \\
\text { (yr) }\end{array}$ & Breast & $\begin{array}{c}\text { Pubic } \\
\text { hair }\end{array}$ & Menses & $\begin{array}{c}\mathrm{LH} \\
(\mathrm{mIU} / \mathrm{ml})\end{array}$ & $\begin{array}{c}\text { FSH } \\
(\mathrm{mIU} / \mathrm{ml})\end{array}$ & $\begin{array}{c}\text { Estradiol } \\
(\mathrm{pg} / \mathrm{ml})\end{array}$ \\
\hline 1 & 4.5 & 107 & 60 & 7.8 & III & IV & + & 2.8 & 0.3 & $21 \pm 2$ \\
\hline 2 & 3.2 & 108 & 97 & 7.8 & IV & III & + & 2.2 & 0.7 & $132 \pm 16$ \\
\hline 3 & 1.2 & 82 & 95 & 2.0 & III & I & + & 1.6 & 0.2 & $133 \pm 22$ \\
\hline 4 & 5.1 & 128 & 97 & 8.8 & IV & III & + & 2.5 & 10.7 & $<20$ \\
\hline 5 & 4.5 & 117 & 97 & 6.8 & IV & II & + & 7.0 & 9.6 & $<20$ \\
\hline 6 & 5.2 & 102 & 25 & 6.0 & II & II & + & 2.0 & 5.7 & $<20$ \\
\hline 7 & 10.5 & 141 & 50 & 12.0 & IV & II & + & 99.8 & 20.0 & $45 \pm 6$ \\
\hline 8 & 8.9 & 152 & 97 & 13.5 & IV & III & + & 123 & 22.8 & $50 \pm 4$ \\
\hline
\end{tabular}

* Data for patients 1,3 to 6 , and 8 has been shown previously (3).

$\dagger$ According to the method of Tanner (9).

Health and Human Development. Informed consent was obtained from a parent and assent was obtained from children more than $7 \mathrm{yr}$ of age.

LHRH stimulation was performed by administration of 100 $\mu \mathrm{g}$ of LHRH intravenous at time 0 and gonadotropin levels were determined at $-30,-15,0,15,30,45,60,90$, and $120 \mathrm{~min}$. Estradiol was determined as the mean of four values obtained at $1000,1400,2200$, and 0200 h. Children with McCune-Albright syndrome were either followed without treatment or treated with the long-acting agonist of LHRH, D-Trp 6 -Pro ${ }^{9}$-NEt-LHRH $\left(\mathrm{LHRH}_{\mathrm{a}}\right)$ at a dose of $4 \mu \mathrm{g} / \mathrm{kg} /$ day subcutaneous. This analog has been shown to supress gonadotropins thereby suppressing estradiol levels in girls with central precocious puberty $(10,11)$, but has not influenced estradiol levels in girls with gonadotropinindependent ovarian estrogen secretion $(4,5)$. Serial ultrasounds and estradiol measurements (mean of four values as above) were obtained in patients $1,2,3$, and 5 at approximately 3-month intervals.

Hormone assays. Serum LH, FSH, and estradiol were measured by modifications of previously described methods (Second International Reference Preparation of Human Menopausal gonadotropin) (12-14). Sensitivity of the estradiol assay was $20 \mathrm{pg} /$ $\mathrm{ml}$, and intra- and interassay coefficients of variation were 8 and $16 \%$, respectively. TSH and prolactin were measured by radioimmunoassay as previously described $(15,16)$.

FSH bioassay. FSH bioactivity was quantified by means of FSH-dependent aromatase activity (conversion of androgen substrate to estradiol). Following decapitation, testes from 7- to 10day-old Sprague Dawley rats were decapsulated and incubated in a combination of Dulbecco's and Ham's F10 (1:1) medium containing $0.03 \%$ collagenase and $0.003 \%$ soybean trypsin inhibitor for $5-10 \mathrm{~min}$ at $34^{\circ} \mathrm{C}$. Medium was decanted to remove interstitial cells. The tubules were washed and resuspended in medium containing $0.03 \%$ collagenase, $0.003 \%$ soy trypin inhibitor, and $0.03 \%$ DNase for $30 \mathrm{~min}$ at $34^{\circ} \mathrm{C}$. Dispersion of Sertoli cells was hastened by mechanical dispersion with a pasteur pipette. The resulting cell suspension was washed three times, and cells resuspended in medium [formulation based on Rich et al. (17)] containing 19-OH androstenedione $(2.5 \mu \mathrm{M})$ and methyl isobutyl xanthine $(0.1 \mathrm{mM})$. One $\mathrm{ml}$ of cell suspension was transferred to each well of a multiwell culture dish (Falcon, diameter $16 \mathrm{~mm}$ ). The cells were washed and reincubated in incubation medium containing increasing concentrations NIAMDD hFSH 1-2 (AFP 2844B, biopotency $3925 \mathrm{IU} / \mathrm{mg}$; immunopotency $5226 \mathrm{IU} / \mathrm{mg}$ ) or with unknown serum samples ( 3 and $5 \mu \mathrm{l}$ ). Following a $24-\mathrm{h}$ incubation, medium was aspirated and assayed for estradiol by radioimmunoassay (18). The sensitivity of the bioassay system was $0.01 \mathrm{ng} / \mathrm{ml}$ and index of precision 0.049 . The assay is specific for FSH bioactivity (19) (Padmanabhan V, unpublished data).

Ultrasonography. Pelvic ultrasonography, using a static Bscanner, duplicated that described by Sample et al. (20). Ovarian volumes were calculated by the 3-dimensional diameters from sagittal and transverse scanning and then using the formula: volume $=0.5$ (width $\times$ thickness $\times$ length $)$.

Statistical analysis. Data are represented as the mean \pm SEM. Statistical comparisons were made by Student's $t$ test. Correlations of estradiol and ovarian volume were determined by least squares linear regression analysis.

\section{RESULTS}

Ovarian volumes in McCune-Albright syndrome and in central precocious puberty. Mean volumes in girls with McCune-Albright syndrome overlapped the range seen in girls with idiopathic or CNS lesion associated central precocious puberty (Fig. 1A). However, when individual ovarian volumes were compared, girls with McCune-Albright syndrome had greater asymmetry of ovarian volume than did the girls with central precocious puberty (Fig. $1 B$ ). The difference in right to left ovarian volume was significantly greater in girls with McCune-Albright syndrome ( $p$ $<0.05$, difference of $5.5 \pm 1.5 \mathrm{ml}$ ) as compared to those with central precocious puberty $(1.5 \pm 0.2 \mathrm{ml})$. In patients 2,3 , and 4 , a cyst of greater than $1 \mathrm{~cm}$ in diameter was present in the larger ovary. In patients 2 through 6 , large cysts were documented at various times, unilaterally, during longitudinal study. The cysts always occurred in the same ovary in patients 3,4 , and 5 . Cysts were documented in both ovaries of patient 2 although asymmetry persisted and the right ovary was always larger than the left when estradiol was elevated. In patient 6 , the left ovary had been previously excised because of the presence of a large ovarian cyst. Subsequently, the right ovary developed a large cyst. In patient 8 , multiple small cysts were noted in both ovaries. Cysts were not seen in ultrasounds of patients 1 and 7 .

Estradiol levels and ovarian volume. The girls with McCuneAlbright syndrome initially presented with estradiol levels ranging from less than 20 to $133 \mathrm{pg} / \mathrm{ml}$ although all had evidence of advanced secondary sexual characteristics and advancement of bone age. This indicated that estradiol levels must have been elevated in all these girls and may have fluctuated over time. We compared the ovarian volumes of the girls with undetectable estradiol levels at their initial visit (less than $20 \mathrm{pg} / \mathrm{ml}$ ) to those with detectable estradiol levels (greater than $20 \mathrm{pg} / \mathrm{ml}$ ). The girls with detectable levels had significantly larger $(7.6 \pm 1.2 \mathrm{ml})$ ovarian volumes than did girls with undetectable estradiol levels $(2.8 \pm 0.8 \mathrm{ml}, p<0.02)$. Patients $1,2,3$, and 5, who had low gonadotropin levels, were followed longitudinally for 1 or more yr at 3- to 6-month intervals with pelvic ultrasound examinations and determination of estradiol levels. These girls had been treated for 3-12 months with $\mathrm{LHRH}_{\mathrm{a}}$ but had shown no decrease in serum gonadotropin levels nor in estradiol fluctuation (5). Over time, mean ovarian volumes fluctuated and were increased in association with elevation of estradiol levels $[r=0.79, p<0.001$ (Fig. 2A)]. Similarly, the differences in right to left ovarian 

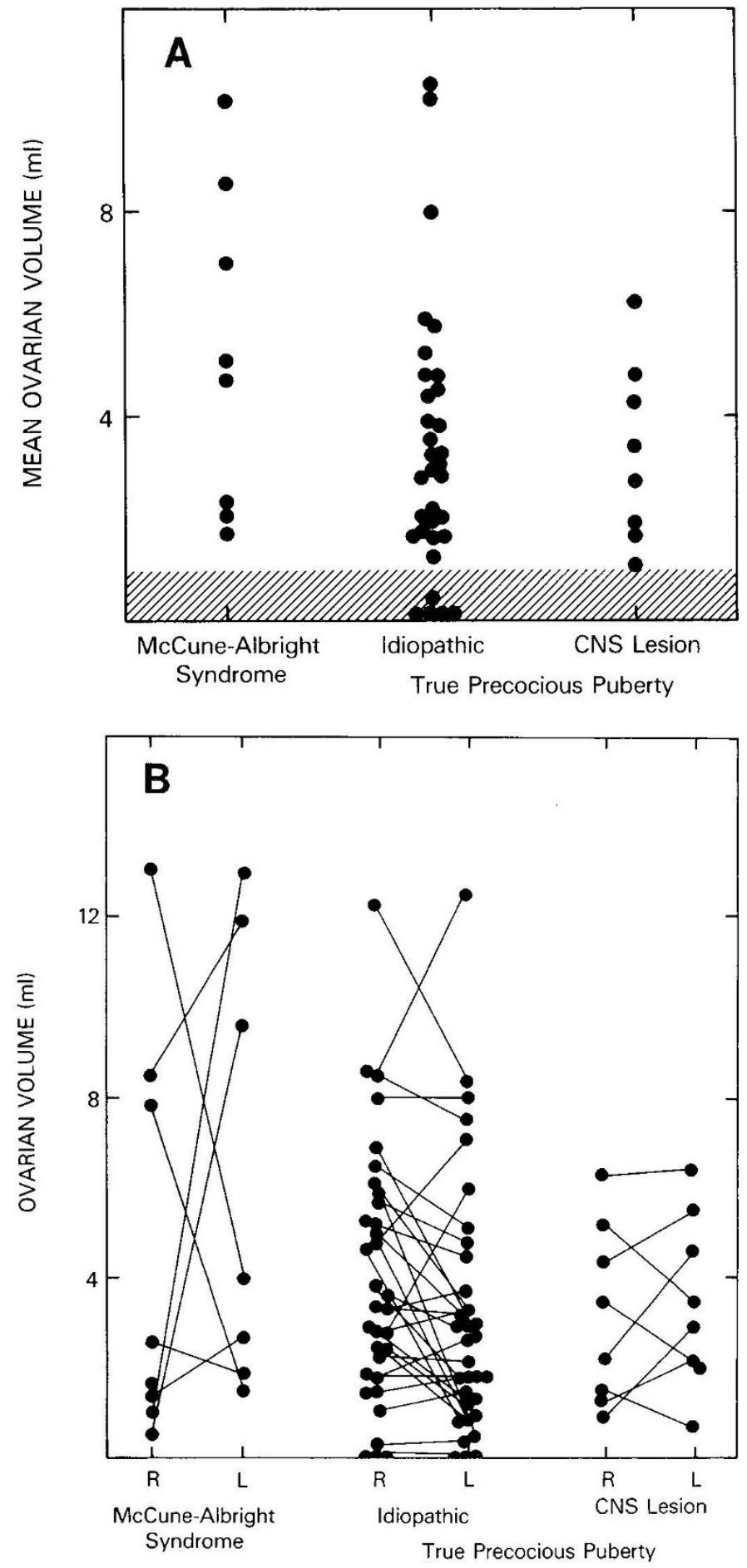

Fig. 1. Ovarian volume of girls with McCune-Albright syndrome as compared the ovarian volume of girls with central true precocious puberty, either idiopathic or associated with a CNS lesion from Shawker et al. (29). Measurements were made by ultrasonagraphy at initial presentation. Volume was determined as $0.5 \times$ (transverse $\times$ sagital $\times$ anterior) diameters of each ovary. $A$, mean ovarian volumes. The shaded area represents the mean ovarian volume of prepubertal subjects $(<0.9$ $\mathrm{ml}) . B$, difference between right and left ovarian volumes.

volume also correlated with increases in plasma estradiol level $[r$ $=0.72, p<0.001$ (Fig. 2B)].

Serum prolactin and TSH levels. Girls with hypothyroidism occasionally develop secondary sexual characteristics and vaginal bleeding in association with large ovarian cysts (20). The cause of precocious puberty in girls with hypothyroidism is unknown

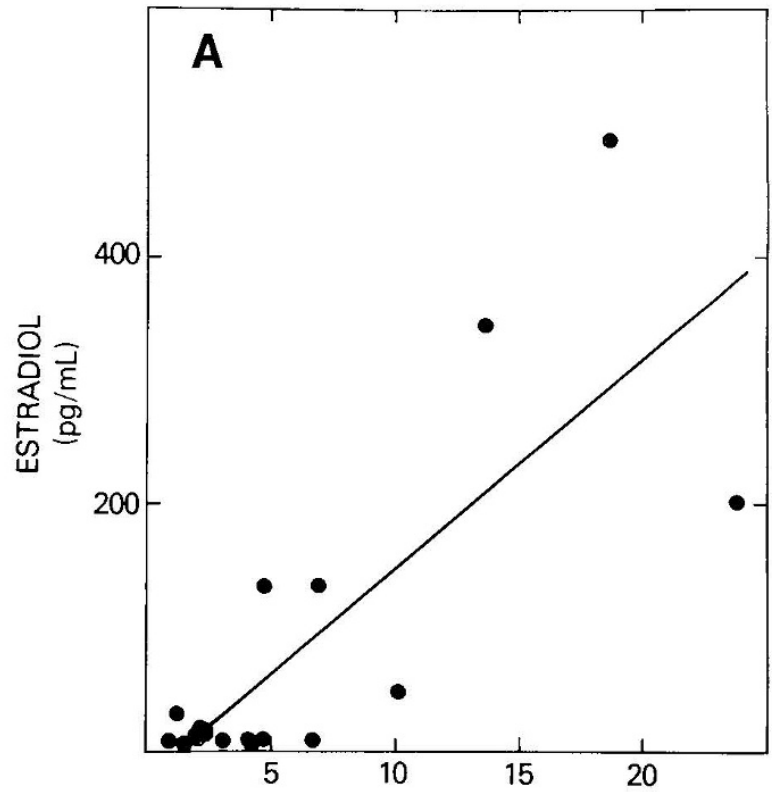

MEAN OVARIAN VOLUME $(\mathrm{mL})$

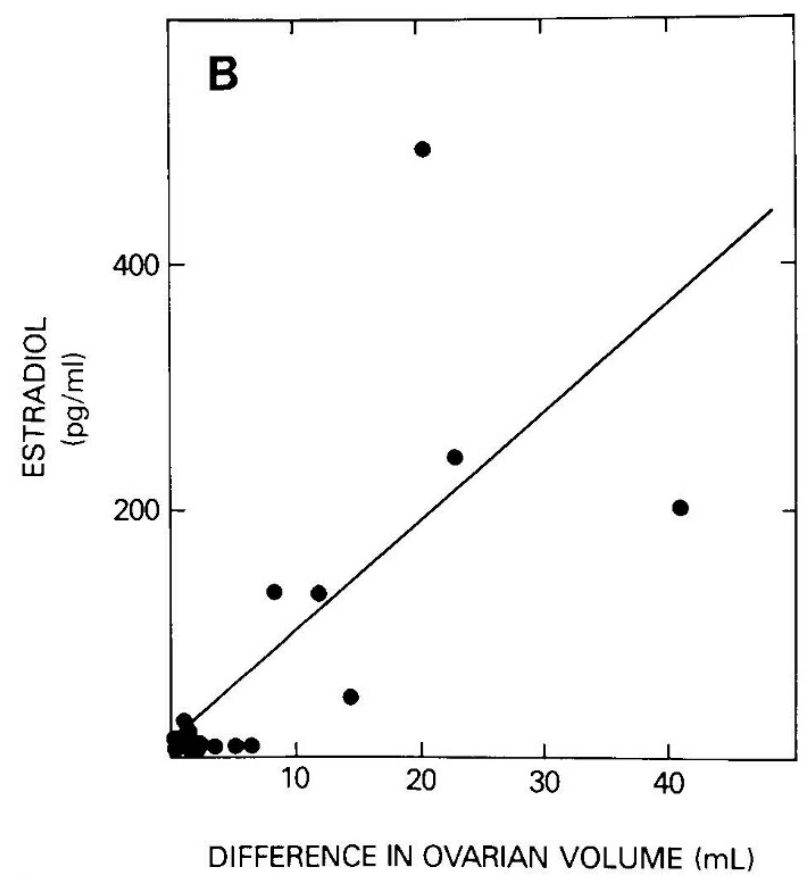

Fig. 2. Plasma estradiol levels and ovarian volume in girls with gonadotropin-independent precocious puberty. Data from patients 1, 2, 3, and 5 , in whom sequential ultrasounds were done, are represented. Patients were either untreated or treated with $\mathrm{LHRH}_{\mathrm{a}}$. Estradiol is expressed as the mean of four samples obtained at 1000, 1400, 2200, and $0200 . A$, comparison of plasma estradiol with mean ovarian volume. $B$, comparison of plasma estradiol with difference between the volumes of the right and left ovaries.

but believed to be related to elevated TSH levels which may, in turn, increase gonadotropin or prolactin secretion. Also, the gonadotropins and TSH share a common $\alpha$-subunit. This potentially might lead to hormonal overlap increasing gonadal activity which would result in precocious puberty. Pituitary hyperfunction has been reported in McCune-Albright syndrome especially for prolactin and growth hormone $(22,23)$. Thus, we examined TSH and prolactin in the six patients with gonadotropin independent precocious puberty (Table 2 ). The TSH levels were 
Table 2. Prolactin and TSH levels

\begin{tabular}{ccc}
\hline Patient & $\begin{array}{c}\text { Prolactin } \\
(\mathrm{ng} / \mathrm{ml})\end{array}$ & $\begin{array}{c}\text { TSH } \\
(\mu \mathrm{U} / \mathrm{ml})\end{array}$ \\
\hline 1 & 11.4 & 2.4 \\
2 & 6.2 & 3.5 \\
3 & 36.2 & 4.0 \\
4 & $\mathrm{NA}^{*}$ & $<2.0$ \\
5 & 3.5 & 3.2 \\
6 & 18.9 & 1.6 \\
Normal range & $<35$ & $<6.0$ \\
\hline
\end{tabular}

* Not available.

Table 3. FSH bioactivity and ovarian volume

\begin{tabular}{|c|c|c|c|}
\hline \multirow[b]{2}{*}{ Patient } & \multicolumn{2}{|c|}{$\begin{array}{l}\text { Ovarian volume } \\
\text { (ml) }\end{array}$} & \multirow{2}{*}{$\begin{array}{l}\text { FSH bioactivity } \\
\text { (ng/ml) }\end{array}$} \\
\hline & Right & Left & \\
\hline 1 & 7.6 & 1.6 & 26.0 \\
\hline \multirow[t]{3}{*}{2} & 3.0 & 1.5 & $<4.0$ \\
\hline & 6.1 & 2.9 & 4.0 \\
\hline & 39.6 & 9.6 & 2.0 \\
\hline \multirow[t]{3}{*}{3} & 1.0 & 13.0 & 8.0 \\
\hline & 0.8 & 3.1 & 4.2 \\
\hline & 1.8 & 3.2 & $<4.0$ \\
\hline \multirow[t]{3}{*}{5} & 2.6 & 0.9 & 22.0 \\
\hline & 16.8 & 4.0 & 20.0 \\
\hline & 1.9 & 0.8 & $<4.0$ \\
\hline Prepubertal normals & $<0.9^{*}$ & $<0.9^{*}$ & $\dagger$ \\
\hline
\end{tabular}

* Based on normals by Sample et al. (19).

$\dagger$ FSH bioactivity has not been detected in normal prepubertal subjects to date.

normal in all subjects tested. Prolactin was slightly increased in one subject at the time she had a large left ovary $(13 \mathrm{ml})$ with a cyst. However, prolactin was normal in the remaining four subjects tested irregardless of ovarian size. None of the patients exhibited hyperthyroidism, as assessed by $\mathrm{T}_{4}$ radioimmunoassay at the time of study.

Serum FSH bioactivity. It is believed that complete ovarian function cannot occur without FSH priming, principally since girls with hCG-producing tumors have not been reported to develop precocious puberty. Our patients with McCune-Albright syndrome appeared to have functioning ovarian cysts but low to suppressed levels of FSH. It is possible that the serum of these girls might have a substance with FSH bioactivity that was not recognized in our FSH radioimmunoassay. FSH bioactivity was determined in serum from patients $1,2,3$, and 5 during periods with small ovaries and periods with large ovarian cysts (Table 3 ). In this bioassay, normal pubertal girls had serum FSH bioactivity of $32 \pm 4 \mathrm{ng} / \mathrm{ml}(n=6)$. Normal adult women in early follicular phase of the menstrual cycle had FSH bioactivity of $202 \pm 71$ $\mathrm{ng} / \mathrm{ml}(n=6)$. We have not been able to detect FSH bioactivity in normal prepubertal subjects to date. In contrast, two girls with McCune-Albright syndrome (patients 1 and 5) had detectable FSH bioactivity despite low levels of FSH by radioimmunoassay. Patient 3 had FSH bioactivity in one sample that was at the borderline of detectability. Unilateral ovarian enlargement was evident by ultrasound at the time $\mathrm{FSH}$ bioactivity was increased in patients 1,3 , and 5 . However, no clearly evident increase in FSH bioactivity was seen in patient 2 at times when large ovarian cysts were present in her ovaries.

\section{DISCUSSION}

Girls with McCune-Albright syndrome may have a number of endocrinological abnormalities in addition to sexual precocity: Those include hyperfunction of the thyroid (24), Cushing syndrome (25), and pituitary abnormalities (22). The cause of the endocrine hyperfunction is, as yet, unknown. Hall and Warrick (26) proposed the etiology was related to abnormal or excessive signals from the hypothalamus. However, the majority of patients with McCune-Albright syndrome and sexual precocity have very low levels of gonadotropins $(3,4,6)$ and do not exhibit further suppression of gonadotropins nor cessation of menses when treated with long-acting agonists of LHRH. Thus, excess neurotransmitters or excess LHRH secretion cannot account for sexual precocity in most girls with McCune-Albright syndrome, and other etiologies must be investigated.

We have documented that all six girls in our study who had gonadotropin-independent precocious puberty also had enlarged ovaries. Five of the six had intermittent presence of large unilateral ovarian cysts. Ovarian growth with cyst formation appears to be responsible for increases in estradiol production in these girls. Surgical examination has shown that these cysts are generally follicular (2). Despite the formation of such cysts, we and others have not demonstrated elevated progesterone levels in any patients indicating that ovulation has not occurred (2) (Foster $\mathrm{CM}$, unpublished observations).

Ovarian cysts have been seen in association with precocious puberty. Notably, girls with severe hypothyroidism may develop large, multicystic ovaries (21) in response to hormonal overlap from TSH or prolactin (27). TSH shares a common $\alpha$-subunit with the gonadotropins. However, none of our patients had high TSH levels. Prolactin levels were normal in four of the five girls tested with gonadotropin-independent precocious puberty. This makes an overlap in hormonal sensitivity less likely in these patients.

Circulating factors with gonadotropin bioactivity but little gonadotropin immunoactivity theoretically could stimulate ovarian growth in our patients. Previously we determined LH bioactivity using the rat interstitial cell testosterone production assay in patients 1 and 3 to 6 (3). LH bioactivity was not detectable in any of the girls with low gonadotropin levels. This is in agreement with others who have determined LH bioactivity in girls with McCune-Albright syndrome (6) (Beitins IZ, unpublished observation). In contrast, FSH bioactivity was detected in at least two of our patients. FSH bioactivity did not correlate well with ovarian cyst presence nor with estradiol level. Thus, the significance of this observation is, as yet, unclear.

The fluctuation of ovarian cyst size with consequent fluctuation of plasma estradiol levels appears to be responsible for sexual precocity in girls with McCune-Albright syndrome. Each girl appears to have her own rhythm of cyst production. Cysts have appeared monthly or bimonthly in some of our patients whereas others had cyst formation and exacerbation of symptoms after prolonged quiescent periods of a year or more. We and others have observed that removal of the cyst results in only temporary improvement as remaining ovarian tissue may form cysts (8). Hence surgical intervention is not usually beneficial. Experimental therapy based on interference with estradiol production by use of aromatase inhibitors such as $\Delta$-1-testolactone has shown more promise (28). The decrease in ovarian cyst size with testolactone therapy suggests that, possibly, there is an imbalance between estrogens and androgens which allows an ovarian cyst to grow. Improved understanding of the cause of ovarian growth in girls with McCune-Albright syndrome will be necessary to improve treatment and outcome.

\section{REFERENCES}

1. Albright F, Butler AM, Hampton AC, Smith PH 1937 Syndrome characterized by osteitis fibrosa disseminata, areas of pigmentation and endocrine dys- 
function. N Engl J Med 216:727-746

2. Benedict $P$ 1966 Endocrine features in Albright's syndrome. Metabolism $11: 30-45$

3. Foster CM, Ross JL, Shawker T, Pescovitz OH, Loriaux DL, Cutler GB Jr 1984 Absence of pubertal gonadotropin secretion in girls with McCuneAlbright syndrome. J Clin Endocrinol Metab 5:1161-1165

4. Comite F, Shawker TH, Pescovitz OH, Loriaux DL, Cutler GB Jr 1984 Cyclical ovarian function resistent to treatment with an analogue of luteinizing hormone releasing hormone in McCune-Albright syndrome. $\mathrm{N}$ Engl $\mathbf{J}$ Med 311:1032-1036

5. Foster CM, Comite F, Pescovitz OH, Ross JL, Loriaux DL, Cutler GB Jr 1984 Variable response to a long-acting agonist of luteinizing hormone-releasing hormone in girls with McCune-Albright syndrome. J Clin Endocrinol Metab 59:801-805

6. Wierman ME, Beardsworth DE, Mansfield M, Badger TM, Crawford JD, Criesler JF, Jr, Bode HH, Loughlin JS, Kushner DC, Scully RE, Hoffman WH, Crowley WF Jr 1985 Puberty without gonadotropins. A unique mechanism of sexual development. N Engl J Med 312:65-72

7. Pray LG 1951 Sexual Precocity in females report of two cases with arrest of precocity in the McCune-Albright syndrome after removal of a cystic ovary. Pediatrics 8:684-692

8. Case records of the Massachusetts General Hospital (case 4-1975) 1975 N Engl J Med 292:199-203

9. Tanner JM 1978 Growth at Adolescence. Blackwell, Oxford

10. Comite F, Cutler GB Jr, Rivier J, Vale W, Loriaux DL, Crowley WF Jr 1981 Short term treatment of idiopathic precocious puberty with a long-acting analogue of luteinizing hormone releasing hormone. $\mathrm{N}$ Engl $\mathrm{J}$ Med 305:1546-1550

11. Mansfield MJ, Beardsworth DE, Loughlin JS, Crawford JD, Bode HH, Rivier J, Vale W, Kushner DC, Criegler JF Jr, Crowley WF Jr 1983 Long term treatment of central precocious puberty with a long-acting analogue of luteinizing hormone-releasing hormone Effects on somatic growth. $\mathrm{N} \mathrm{Engl}$ J Med 309:1286-1290

12. Cargille CM, Rayford PL 1970 Characterization of antiserum for human follicle stimulating hormone radioimmunoassay. J Lab Clin Med 75:1030-1040

13. Odell WD, Ross GT, Rayford PL 1967 Radioimmunoassay for luteinizing hormone in human plasma or serum physiological studies. J Clin Invest 46:248-255

14. Loriaux DL, Ruder HT, Lipsett MB 1971 The measurement of estrone sulfate in plasma. Steroids 18:463-472

15. Aubert Al, Becker RL, Saxina AA, Raiti S 1974 Report of the National
Pituitary Agency. Collaborative study of the radioimmunoassay of human prolactin. J Clin Endocrinol Metab 38:1115-1120

16. Ridgeway EC, Weintraub BD, Ceballos JL, Rack MC, Maloof FF 1973 Suppression of pituitary TSH secretion in the patient with hypersecreting thyroid modules. J Clin Invest 52:2783

17. Rich K, Bardin CW, Gunsalus G, Mather J 1983 Age-dependent pattern of androgen binding protein secretion from rat Sertoli cells in primary culture. Endocrinology 113:2284-2293

18. England BG, Niswender GD, Midgley AR 1974 Radioimmunoassay of estradiol 17 beta without Chromatography. J Clin Endocrinol Metab 38:42-50

19. Padmanabhan V, Chappel SC, Beitins IZ 1985 An improved in vitro FSH bioassay suitable for the measurement of hFSH in serum. The Endocrine Society Program and Abstracts of the 67th Annual Meeting. 1136A

20. Sample W, Dippe BM, Gypes MT 1977 Gray scale ultrasonography of the normal female pelvis. Radiology 125:477-483

21. Lindsay AN, Voorhess ML, MacGillivray MH 1980 Multicystic ovaries detected by sonography in children with hypothyroidism. Am J Dis Child 134:589-592

22. Lightner ES, Penny R, Frasier SD 1975 Growth hormone excess and sexual precocity in polyostotic fibrous dysplasia (McCune-Albright syndrome): evidence for abnormal hypothalamic function. J Pediatr 87:922-927

23. Carr D, Mathie K, Manners AR, Colman C 1975 Br J Obstet Gynecol 86:330331

24. Hamilton CR, Maloof F 1973 Unusual types of hyperthyroidism. Medicine 52:195-215

25. Danon M, Robboy S, Kim S, Scully R, Crawford JD 1975 Cushing syndrome, sexual precocity, and polyostotic fibrous dysplasia of bone (Albright syndrome) in infancy. J Pediatr 87:917-921

26. Hall R, Warrick C 1972 Hypersecretion of hypothalamic releasing hormones. A possible explanation of the endocrine manifestations of polyostotic fibrous dysplasia (Albright syndrome). Lancet 1:1313-1316

27. VanWyk JJ, Grumbach MM 1960 Syndrome of precocious menstruation and galactorrhea in juvenile hypothyroidism: an example of hormonal overlap in pituitary feedback. J Pediatr 57:416-435

28. Foster CM, Pescovitz OH, Comite F, Shawker T, Loriaux DL, Cutler GB Jr 1985 Testolactone treatment of precocious puberty due to McCune-Albright syndrome. Acta Endocrinol 109:254-257

29. Shawker TH, Comite F, Rieth KG, Dwyer AJ, Cutler GB Jr, Loriaux DL 1984 Ultrasound evaluation of female isosexual precocious puberty. J Ultrasound Med 3:309-316 